\title{
Radium-223: Insight and Perspectives in Bone-metastatic Castration-resistant Prostate Cancer
}

\author{
FEDERICA ELEONORA BURONI ${ }^{1}$, MARCO GIOVANNI PERSICO ${ }^{1}$, FRANCESCA PASI $^{2}$, \\ LORENZO LODOLA $^{1}$, ROSANNA NANO $^{3}$ and CARLO APRILE ${ }^{1,4}$ \\ ${ }^{1}$ Nuclear Medicine Unit, and ${ }^{2}$ Radiotherapy Unit, Department of Oncohaematology, \\ Fondazione IRCCS Policlinico San Matteo, Pavia, Italy, \\ ${ }^{3}$ Lazzaro Spallanzani Department of Biology and Biotecnology, University of Pavia, Pavia, Italy; \\ ${ }^{4}$ Fondazione CNAO, National Centre of Oncological Hadrontherapy, Pavia, Italy
}

\begin{abstract}
Ra prolongs overall survival in symptomatic patients affected by multiple bone-metastatic castrationresistant prostatic cancer, without visceral or nodal involvement. However, many questions remain about its mechanisms of action, and its use in clinical practice is still unresolved. First of all, what is the main target of alphaparticle emission, that is, in what way does it influences the tumor microenvironment? When is the best timing in the course of the disease, extending its use to asymptomatic lowvolume or even to the micrometastatic phase? What are suitable biomarkers to be employed as prognostic factors and response indicators? Which associations with other drugs and their sequence can offer the best results, and is their effect additive or synergistic? Ultimately, in the current climate of spending review, what is the optimal cost and benefit ratio regarding available treatments? In this review, we tried to answer these questions by analyzing the available scientific literature.
\end{abstract}

Prostate cancer $(\mathrm{PCa})$ is the most common malignancy in men (1). In patients affected by advanced $\mathrm{PCa}$, defined as hormonesensitive disease since the tumor still requires androgen for growth, androgen deprivation therapy (ADT), including luteinizing hormone-releasing hormone (LHRH) agonists,

This article is freely accessible online.

Correspondence to: Dr. Carlo Aprile, Nuclear Medicine Unit, Fondazione IRCCS Policlinico San Matteo, Viale Golgi 19, 27100 Pavia, Italy. E-mail: c.aprile@smatteo.pv.it

Key Words: Radium-223, castration-resistant prostatic cancer, radiometabolic therapy, bone metastases, palliation of pain, pharmacoeconomics, review. antagonists and anti-androgens, represents the first-line treatment. Unfortunately some cancer cells develop resistance to ADT, indicating the progression of the disease to metastatic castration-resistant prostate cancer (mCRPCa). Such resistance to castration occurs in most patients (2) and, despite the approval of new therapeutic agents, mCRPCa remains a lethal disease (3). Nowadays the new therapeutic landscape for patients affected by mCRPCa aims to extend overall survival (OS) and includes cytotoxic, new-generation anti-androgens, immunotherapeutics and radiopharmaceuticals $(4,5)$.

Bones are the preferred site of metastasis. Almost $90 \%$ of men who die from PCa have bone-metastatic disease (6), with a 5 -year OS rate of $20 \%$. Due to the fragility of bone with metastases, with the related risk of pain, fractures, spinal cord compression and hematological consequences, several drugs have been developed to treat the osseous involvement of this disease. In previous years, the optimal treatment aimed to relieve pain and reduce skeletal morbidity.

Besides systemic therapies, bone-targeted agents that focus their activity on bone, such as bisphosphonates, monoclonal antibody and radiopharmaceuticals, have become available. The bisphosphonate zoledronic acid, the antibody to receptor activator of nuclear factor kappa-B ligand (RANKL) denosumab and radiopharmaceuticals [such as ${ }^{89} \mathrm{Sr}$ and ${ }^{153} \mathrm{Sm}$-ethylene diamine tetramethylene phosphonate $\left({ }^{153} \mathrm{Sm}\right.$-EDTMP)], were approved for delaying skeletal-related events (SREs) and for the palliation of bone pain from mCRPCa.

\section{Radionuclide Therapy}

Radionuclide therapy is known to deliver ionizing radiation to tumor sites, thereby killing cancer cells (7). Bone-targeted radiopharmaceuticals localize their radiation to sites of high bone remodeling. 
The first beta particle-emitting radiopharmaceuticals were considered only to be able to palliate pain as the long range of beta-particle radiation (several millimeters) is thought to irradiate cells near the target tumor, causing bone marrow depletion. As a side-effect of such therapy, thrombocytopenia is more common than neutropenia, and this represents a limiting factor that does not allow repeated administrations (8). Although these radiopharmaceuticals may confer a benefit in terms of survival, their impact on OS has not been studied in adequately designed trials (9).

Disregarding ${ }^{32} \mathrm{P}$, whose use was abandoned due to high myelotoxicity, and ${ }^{117} \mathrm{~m}$ Sn-diethylenetriaminepentaacetic

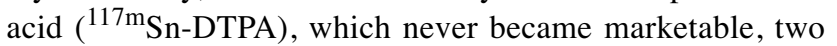
beta-emitting bone seekers are actually on the market: ${ }^{89} \mathrm{Sr}-$ chloride and ${ }^{153} \mathrm{Sm}$-EDTMP.

${ }^{89} \mathrm{Sr}$-Chloride is a pure beta particle-emitting calcium analog (half-life of 50.5 days, beta energy of $1.5 \mathrm{MeV}$ ) with potential tumoricidal effect. It is taken up into inorganic bone matter and is able to palliate bone pain in a dose-related manner. It reduces the incidence of spinal cord compression and slightly increases the median OS if associated with chemotherapy (10). Its main disadvantage is hematological toxicity due to its $2.4 \mathrm{~mm}$ range of tissue penetration. The nadir of platelet depression was reported to be 4-6 weeks or 12-16 weeks with 6-week-long duration. The response time was 2 or 3 weeks in $65-90 \%$ of patients (11).

${ }^{153} \mathrm{Sm}$-EDTMP (half-life 1.9 days, $28 \%$ gamma emission, which allows the scintigraphic evaluation of dosimetry and biodistribution) penetrates tissue to $0.6 \mathrm{~mm}$, leading to doserelated pain relief although with a mild myelosuppression (1215). Pain reduction begins between 1 to 4 weeks and persists as long as 17 weeks (11). The nadir of platelet and white cell reductions was between 3 to 6 weeks after injection, with complete recovery by week 8-9 (15-18), less delayed and shorter in duration than with ${ }^{89} \mathrm{Sr}$. There is no evidence regarding samarium improving OS when used as a single agent but this was hypothesized when ${ }^{153} \mathrm{Sm}$ is used sequentially or combined with docetaxel (19-21) or immunotherapy (22).

On the other hand, alpha particle-emitting nuclides characterized by a narrow path length and high linear energy transfer value are able to deliver their energy with a smaller diameter, inducing double-strand DNA breaks, leading to irreparable DNA damage and cell death, sparing the neighboring non-targeted areas such as the bone marrow, in the case of bone seekers. Alpha particles are considered more cytotoxic than beta particles, especially under hypoxic conditions $(23,24)$ and, because of their higher biological efficacy, the required activity is lower than that of beta particles.

\section{Radium-223 Chloride}

The history of radium isotopes in medicine spans more than a century. ${ }^{223} \mathrm{Ra}$ was the pioneer alpha particle-emitting agent (half-life of 11.4 days, $95.3 \%$ of the total decay energy released as alpha particles, $3.6 \%$ as beta particles and $1.1 \%$ as gamma rays) (25) approved by national agencies as therapeutic radiopharmaceutical. The median and maximum path length are 60 and $100 \mu \mathrm{m}$ respectively with a linear energy transfer value of $80 \mathrm{KeV} / \mu \mathrm{m}$.

${ }^{223} \mathrm{Ra}$ is a bone-targeting agent rather than a specific cancer-targeting one. Mimicking calcium ions, it is adsorbed at sites of active mineralization in bone (26), concentrating at the bone surface without the need for a carrier molecule. It forms complexes with hydroxyapatite, in particular in areas characterized by high osteoblastic turnover, such as PCa metastatic foci where osteoblasts surround PCa cells.

${ }^{223} \mathrm{Ra}$ is rapidly cleared from the bloodstream after intravenous administration, with a volume of distribution of about 231 . About $14 \%$ is present in plasma at the end of infusion, $2 \%$ at $4 \mathrm{~h}$ and less than $1 \%$ at $24 \mathrm{~h}$. The main route of excretion is intestinal (about $51 \%$ at $24 \mathrm{~h}$ ), while urinary excretion is negligible, approximately $5 \%$ (27).

\section{Experimental Data}

The in vitro action of ${ }^{223} \mathrm{Ra}$ was investigated by Suominen and co-workers, who showed an inhibitory effect on proliferation of breast cancer cells and differentiation of osteoblasts and osteoclasts (28).

Significant antitumoral effect was demonstrated in an experimental osseous metastasis model in nude rats which received $10^{6} \mathrm{MT}-1$ human breast cancer cells. Animals receiving $\geq 10 \mathrm{kBq}$ of ${ }^{223} \mathrm{Ra}$ had a significant symptom-free survival, about $40 \%$ of them were alive beyond the 67 -day follow-up period, while untreated animals had to be sacrificed 20-30 days after injection because of tumorinduced paralysis. No bone marrow toxicity was detectable (29). The same group estimated the dose to marrow cavities in mice and showed that the ${ }^{223} \mathrm{Ra}$ alpha-particle emitter might have a marrow-sparing advantage compared with the beta particle-emitter ${ }^{89} \mathrm{Sr}(30)$.

In a mouse model of breast carcinoma skeletal metastasis, ${ }^{223} \mathrm{Ra}$ as monotherapy prevented tumor-induced cachexia, reduced osteolysis and augmented survival, with further improvement if associated with zoledronic acid or doxorubicin. A very interesting finding was that more pronounced effects were observable if ${ }^{223} \mathrm{Ra}$ was administered in a preventative or micrometastatic setting (28).

In a naïve and mouse model of PCa bone metastasis Abou et al. observed that $\mathrm{Ra}$ accumulation did not correspond to bone volume or surface area but to local blood vessel density. Blastic and lytic lesions exhibited the same uptake, approximately equal to that of normal remodeling bone (31). 


\section{Clinical Studies}

While the studies about older bone-targeting radiopharmaceuticals focused on pain relief, with the introduction of ${ }^{223} \mathrm{Ra}$, OS became the primary endpoint and symptomatic skeletal-related events (SREs), quality of life and biochemical responses were the secondary endpoints. The Committee for Medicinal Products for Human Use of the European Medicinal Agency accepted Xofigo ${ }^{\circledR}$, whose active component is ${ }^{223} \mathrm{Ra}$ dichloride, and accelerated its placement in clinical praxis based on the therapeutic innovation, considering the unmet medical needs and the novel mechanism of action (32).

The ALSYMPCA trial was the main multicentric pivotal study for ${ }^{223} \mathrm{Ra}$. It randomized 921 patients with bonemetastatic hormone-refractory PCa to receive either ${ }^{223} \mathrm{Ra}$ chloride $(50 \mathrm{kBq} / \mathrm{kg}$ i.v., at 4-week intervals) or placebo for four or six doses, both in combination with the best standard of care [local external beam radiation therapy (EBRT), corticosteroids, anti-androgens, estrogens and estramustine]. The main inclusion criteria were serum testosterone $\leq 50 \mathrm{ng} / \mathrm{dl}$, bilateral orchiectomy or current therapy with LHRH analogs, prostate-specific antigen (PSA) progression, at least two symptomatic skeletal metastases on bone scintigraphy, symptomatic disease, no visceral metastases, no scheduled chemotherapy within the following 6 months, Eastern Cooperative Oncology Group (ECOG) performance status $0-2$ and a life expectancy $\geq 6$ months.

Exclusion criteria were treatment with cytotoxic chemotherapy within the previous 4 weeks or radionuclide therapies for body metastases within the previous 24 weeks, malignant lymphadenopathy $\geq 3 \mathrm{~cm}$ in diameter, spinal cord compression on magnetic resonance imaging, other malignancy treated in the previous 5 years (with the exception of non-melanoma skin cancer or low-grade bladder cancer). Concurrent use of abiraterone or enzalutamide was not permitted. Patients were stratified on the basis of baseline alkaline phosphatase (ALP) level, bisphosphonate use and previous docetaxel therapy.

In this landmark trial, Xofigo ${ }^{\circledR}$ demonstrated its efficacy in improving OS [14.9 months vs. 11.3 months; hazard ratio $(\mathrm{HR})=0.70,95 \%$ confidence interval $(\mathrm{CI})=0.58-0.83$; $p=0.00185)$ as early as the first pre-specified interim analysis, planned after 320 events (33) regardless of the extent of disease, previous docetaxel or concurrent bisphosphonates $(34,35)$. The time to first symptomatic SREs (15.6 vs. 9.8 months; $\mathrm{HR}=0.66,95 \% \mathrm{CI}=0.52-0.83$; $p<0.001)$ (36), time to increased ALP (HR $=0.17,95 \%$ $\mathrm{CI}=0.13-0.22 ; p<0.001)(35)$ and time to increased PSA $(\mathrm{HR}=0.64,95 \% \quad \mathrm{CI}=0.54-0.77 ; \quad p<0.001)$ were also prolonged.

The quality of life was improved $(p=0.02)$ and deterioration in ECOG-PS of 2 or more points was significantly lower in the ${ }^{223}$ Ra-treated group $(H R=0.62$, 95\% CI=0.46-0.85; $p=0.003)$; decline in serum ALP level from baseline was seen more frequently with ${ }^{223} \mathrm{Ra}(87 \% \mathrm{vs}$. $23 \%, p<0.001)$.

The safety of ${ }^{223} \mathrm{Ra}$ was also demonstrated since grade 3 and 4 myelotoxicity were infrequent $(37,38)$. Nadir of myelotoxicity occurred at 2-4 weeks after treatment and recovery was in 24 weeks (34). In any case, myelosuppression was dose-related and reversible. However, more common nonhematological toxicities, such as diarrhea, nausea, vomiting and fatigue, were more frequent than with other novel therapies, such as abiraterone and enzalutamide, although easily manageable (33). In Nilsson et al.'s studies, constipation was reported more frequently than in the placebo-treated group $(37,38)$. Patients pretreated with docetaxel or having a greater extent of osseous disease ( $>6$ metastases) seemed to have a slightly higher risk of myelosuppression. They were at higher risk of grade 3-4 thrombocytopenia or grade 2-3 anemia (39-41). Pain relief duration was 44 days at the approved dose of $50 \mathrm{kBq} / \mathrm{kg}$.

There are several critical issues regarding the ALSYMPCA trial. After the planned interim analysis (OS of 14 vs. 11.2 months for the experimental and control arm respectively, $\mathrm{HR}=0.70 ; p=0.002$ ), the study was unblinded and the independent data monitoring committee recommended early trial discontinuation and crossover of patients in the placebo group to radium-223 treatment. At the planned 3-year follow-up analysis, the OS was 14.9 vs. 11.3 months $(\mathrm{HR}=0.70,95 \% \mathrm{CI}=0.58-0.83 ; p<0.001)$. However, this early stopping carries the risk of an overestimation of OS benefit (42).

In addition it is important to recognize that ${ }^{223} \mathrm{Ra}$ was never administered as a monotherapy but always in combination with hormonal agents, dexamethasone, ketokonazole and antiandrogens. A total of $87 \%$ of patients had 0-1 ECOG performance status and, in our opinion, the population with ECOG performance status of 2 or more was too small for transferability of results to a routine clinical context.

Docetaxel-naïve patients were poorly represented in the ALSYMPCA trial (43\%) and the selection of patients who did not require chemotherapy remained very difficult.

On the basis of the results of the ALSYMPCA trial, national medicinal agencies imposed eligibility criteria for ${ }^{223} \mathrm{Ra}$ treatment accessibility (6). These eligibility criteria are the definitive diagnosis of symptomatic CRPCa, with only prostate bed and bone localization, serum testosterone level lower than $50 \mathrm{ng} / \mathrm{dl}$, M1 stage, no previous treatment with ${ }^{223} \mathrm{Ra}$ or concomitant treatment with abiraterone, enzalutamide or other chemotherapic agents, with an ECOG performance status lower than 4 . There is no mention of previous docetaxel treatment or not. Sequencing and combination of available drugs with their synergistic or indesiderable additive effects are still unsolved questions, as 
well as questions related to which treatment is characterized by a better cost to benefit ratio.

In general, the accessibility of drugs and patient comorbidity affect the choice of treatment. The National Institute for Clinical Excellence (NICE; UK) also recommends considering the performance status. As reported by Omlin et al., all survival-prolonging treatments can be recommended in $\mathrm{mCRPCa}$, it being shrewd to inform patients with more advanced disease of the lower response rate (43).

Docetaxel is a chemotherapeutic agent of the taxane class, able to inhibit microtubules. Since $2004,75 \mathrm{mg} / \mathrm{m}^{2}$ docetaxel administered 3-weekly represents the gold standard drug for CRPCa and in combination with prednisone represents the accepted standard first-line chemotherapy regimen for mCRPCa $(44,45)$. Docetaxel confers moderate benefits in terms of OS and is associated with significant gastrointestinal toxicity, neutropenia and neuropathy (8). NICE recommends docetaxel if the performance status is good.

Several clinical trials showed increased toxicity and no survival advantage from combining docetaxel with other agents (43) and the role of other treatments in pre, post, or concomitant docetaxel settings is still under discussion.

Sipuleucel-T is an anticancer vaccine able to improve OS in patients with asymptomatic or minimally symptomatic mCRPCa, designed for the earlier stage of the disease, in a pre-docetaxel setting (46).

Abiraterone and enzalutamide are molecules belonging to the new-generation anti-androgen class. The former is a new molecule targeting an enzyme in the androgen synthetic pathway. In combination with prednisone or prednisolone, it was initially approved for asymptomatic or mildly symptomatic patients who have failed a previous docetaxel regimen, and more recently for patients intolerant to chemotherapy $(47,48,49)$. Enzalutamide was initially available for second-line therapy of CRPCa and subsequently demonstrated efficacy in prolonging survival in the prechemotherapy setting $(33,50,51,52)$.

Bisphosphonates, zoledronic acid (53) and mostly antibodies to RANKL (denosumab) are able to delay SREs (20), the combined use of these agents with ${ }^{223} \mathrm{Ra}$ can achieve a synergistic effect $(6,35)$. In addition prostatespecific membrane antigen (PSMA) seems to be a promising diagnostic and therapeutic target (54) for CRPCa even if it has not been tested in humans yet.

Therefore, if other beta-emitting radiopharmaceuticals were considered as a last option for patients not amenable to other pharmacological therapies, the use of ${ }^{223} \mathrm{Ra}$ as first-line therapeutic agent or in subsequent lines of therapy is a challenge for physicians (55).

NICE guidance recommended ${ }^{223} \mathrm{Ra}$ post docetaxel-based treatment as second-line option and abiraterone for patients affected by mCRPCa previously treated with docetaxel (56). The only comparison between ${ }^{223} \mathrm{Ra}$ and abiraterone is an indirect one (57). The National Comprehensive Cancer Network guidelines considered ${ }^{223} \mathrm{Ra}$ as first- or second-line option (58). It is necessary to underline that each drug is primarily utilized in the same setting as its pivotal trial. For instance, sipuleucel-T was tested in symptomatic or mildly symptomatic patients with mCRPCa, who were mostly docetaxel naïve, so it was designed for the pre-docetaxel setting (46). The new hormonal agents abiraterone and enzalutamide were originally studied and registered in the post-docetaxel setting, but due to evidence-based medicine findings, the first has already been transferred to the prechemotherapy territory (48). The second will be soon shifted to the same context of chemotherapy-naïve patients.

Of course, while the past custom was a watchful and waiting approach, in the current period, best supportive care adopted in the ALSYMPCA trial is no longer considered the standard of care for mCRPCa.

Saad et al.'s (59) and Sartor et al.'s (60) findings showed that previous treatment with abiraterone or enzalutamide seemed to reduce the probability of completing the assigned six cycles of ${ }^{223} \mathrm{Ra}$; this could justify the employment of ${ }^{223} \mathrm{Ra}$ as first approach for mCRPCa. These findings could reflect the worse prognoses of patients who failed hormonal therapies or they could suggest the earlier use of ${ }^{223} \mathrm{Ra}$ as first lines of therapy. Others proposed the use of more toxic docetaxel or cabazitaxel only after hormonal agents or ${ }^{223} \mathrm{Ra}$ become ineffective (61). Saad et al. in their analyses verified longer OS in patients who received ${ }^{223} \mathrm{Ra}$ with concomitant abiraterone, enzalutamide or both compared to patients who received ${ }^{223} \mathrm{Ra}$ alone, and observed a longer OS in patients who were abiraterone and enzalutamide naïve at baseline (5). Co-treatment with ${ }^{223} \mathrm{Ra}$ and denosumab was also able to increase OS. An advantage of this trial was that it was well representative of currently treated patients with mCRPCa, including both symptomatic and asymptomatic patients and those who had received newly hormonal therapies. All combinations were generally safe. No difference in survival was found associated with previous docetaxel use. Although supporting the strategy of ${ }^{223}$ Ra based combinations to overcome resistance, these data are not sufficient to ensure efficacy in all patients. Further studies will be necessary to confirm these findings.

Taneja considers ${ }^{223} \mathrm{Ra}$ chloride administrable concomitantly with chemotherapy (62), but this is still to be proven and not yet allowed in Italy.

Another aspect that should be analyzed is that other drugs could be administered until disease progression or tolerability, while the repeatability of the ${ }^{223} \mathrm{Ra}$ treatment has been not explored.

\section{Mechanism of Action}

The radiopharmaceutical site of deposition is another considerable factor in predicting the effectiveness of the 
treatment. In fact, radiopharmaceuticals act both volumetrically and superficially on bone and, mostly for short-range particles, they must reach the nucleus of the cell where they can interact with DNA and exert their killing action. Regarding this, Guerra Liberal et al. underlined that ${ }^{223} \mathrm{Ra}$ alpha particles seemed an optimal strategy for the treatment of bone micrometastases (63). Is micrometastatic disease the only setting for the usefulness for the short range of action of ${ }^{223} \mathrm{Ra}$ ? The physically larger alpha particle manifests a shallow penetration until the cortical bone region where the metastases should be located (64). In their model, for the estimation of osseous radiation absorption, Hobbs $e t$ $a l$. attested that the majority of radiation dose is deposited near the trabecular elements (65). Moreover, dosimetric considerations indicated that assuming a $0.67 \mathrm{~Bq} / \mathrm{mm}^{2}$ dose of ${ }^{223} \mathrm{Ra}$ on the surface of a sphere with $250 \mu \mathrm{m}$ radius, the estimated absorbed dose quickly decreased from 65 Gy to $0 \mathrm{~Gy}$ at from $5 \mu \mathrm{m}$ to $70 \mu \mathrm{m}$ deep, respectively. In such a way, ${ }^{223} \mathrm{Ra}$ can deliver a lethal dose to small foci of cancer cells or micrometastases (30). In addition, ${ }^{223} \mathrm{Ra}$ uptake in the bone microenvironment surrounding metastatic foci is approximately the same in both osteolytic and osteoblastic tumors, opening new perspectives for the treatment of other cancer types (31).

Alpha-particle emitters are more toxic towards single cells than beta ones (66), but it is unknown if the larger skeletal tumor burden is irrelevant in the efficacy of ${ }^{223} \mathrm{Ra}$. Due to the short range of action, which confers very low hematological toxicity, alpha particles might not be able to reach the inner marrow areas where frequently prostate cancer cells are detected (67), nor the inner part of larger metastases, even if of few millimeters in diameter. Regarding Shore's declaration that ${ }^{223} \mathrm{Ra}$ directly targets the cells of bone metastases, another aspect to be considered is the fundamental interaction between $\mathrm{PCa}$ cells and the bone environment, which is not yet well understood (64).

The efficacy of ${ }^{223} \mathrm{Ra}$ might be due to an effect on the microenvironment, including vessels and stroma, which induces tumor regression. This concept allows us to shift attention from cancer cells to the tumor microenvironment. PCa cells require additional events in order to colonize bones $(68,69)$. Bones must provide a favorable environment to promote tumor cell attachment, as previously described by Paget in his 'seed and soil' theory, which explained metastasis organ-specificity (70).

More recently the 'pre-metastatic niche model' proposed by Psaila and Lyden assumes that the remodeling of the distant metastatic site precedes homing, colonization and proliferation of cancer cells in the microenvironment of bone niches (71). This is a complex mechanism, not yet fully understood and involving many non-tumoral cell types and a cascade of events mediated by several cytokines and chemokines that drive PCa metastasis to the bone. Hormones and peptides derived from cancer cells drive osteoblasts to produce RANKL for bone resorption (72).

Bone affected by PCa metastases undergoes the action of osteoclasts that promotes their resorption and loss, with consequent compensatory reparative osteoblastic action.

The peri-tumoral environment not only comprises of bone components and cancer cells, but also cancer-associated fibroblasts, pericytes and matrix proteins, which aid tumor cells to invade the stromal compartment for vasculature and lymphatic penetration and distant dissemination. Growth factors released by the matrix lead cancer cells to proliferate. Osteoblasts surrounding the PCa-metastatic niches are also able to secrete chemotactic factors.

This context could explain why not every patient with circulating tumor cells manifests metastatic disease. Why PCa prefers bone as a site for metastasis, why metastasis is predominantly blastic, and what initiates tumor metastasis remain partially unexplained (72).

It is quite surprising that in practice few or no efforts have been made to investigate the effect of ${ }^{223} \mathrm{Ra}$ on the cells constituting the microenvironment, neither in terms of lethality nor in modification of chemical mediators. A deeper insight into this mechanism might provide the rationale for its association with or sequential use with other innovative or commonly employed drugs. In addition, basic research might shed light on a possible effect on interacting stromal cells, in the proximity of which cancer cells with stem-cell like characteristics survive as non proliferating (dormant) cells which are resistant to most therapeutic interventions and start to proliferate when receiving the appropriate signal from the stroma (73).

Assuming therefore that the main target of ${ }^{223} \mathrm{Ra}$ might be the tumor microenvironment, there could be some analogies with the effect of tasquinimod on bone metastatic CRPCa, which reduces the establishment and the progression of metastases through a combination of effects on the metastatic niche, homing and osteogenesis, along with immunomodulation (74).

\section{Prognostic Factors}

As emphasized by the Prostate Cancer Working Group 3 (75), the prediction of outcome and the minimally-invasive assessment are important for the biological characterization of PCa. These features could aid in postulating a therapeutic effect and in identifying the best patient for whom a specific agent is the most appropriate. It is quite intuitive that the bone-metastatic tumor burden, generally speaking, constitutes an adverse prognostic factor. In this regard it is known that bone-related parameters are strong prognostic variables for OS in patients with bone metastases from CRPCa, in addition to the PSA level (76).

Etchebehere et al. found that quantitative evaluation of the skeletal burden, derived from ${ }^{18} \mathrm{~F}$-positron-emission tomography 
(PET) strongly correlates with OS after ${ }^{223} \mathrm{Ra}$ therapy and constitutes an independent predictor, while visual analysis only, despite some degree of correlation, is not a suitable predictor (77). On the other hand, such evaluation is not a suitable predictor of progression-free survival. From the clinical point of view therefore, quantitative ${ }^{18} \mathrm{~F}$-PET is an important imaging modality to guide therapeutic strategies, being able to discriminate candidate responders from non-responders to ${ }^{223} \mathrm{Ra}$ therapy and to identify those at higher risk of SREs during or after therapy. The same study further confirmed visceral and nodal metastases as being univariate predictors of OS.

If the diagnostic accuracy of visceral metastases is quite high employing the common diagnostic modalities such as ultrasound, magnetic resonance imaging, computed tomography and PET, the detection rate of lymph node involvement is suboptimal. Halabi et al. reported a ratio of 1.4 between patients with bone metastases only and those with bone plus lymph node metastases (78).

A PET approach likely offers a higher detection rate than other common diagnostic modalities, even if results are quite conflicting as far as radiopharmaceutical, patient population and stage of disease are concerned. In a meta-analysis with ${ }^{11} \mathrm{C}$-choline PET, the detection rate for nodal involvement from pooled data was only $36 \%$ (95\% CI=22-50\%) (79), while others reported an overall accuracy of $83 \%$ with ${ }^{18} \mathrm{~F}$ choline, a significantly higher sensitivity and a similar specificity in comparison to dedicated computed tomography (80). ${ }^{68} \mathrm{Ga}$-PSMA, being the gold standard for histopathology, has a better performance than ${ }^{18} \mathrm{~F}$-choline for the detection of nodal involvement (81). In other words, we are far from being able to validate a diagnostic method able to stage nodal involvement correctly and therefore identify potentially full responders to ${ }^{223} \mathrm{Ra}$ therapy.

\section{Response Evaluation}

The main problem in assessing response of bone metastases to therapy is the lack of a reliable method, and these lesions are generally not correctly evaluable by Response Evaluation Criteria in Solid Tumors criteria (82).

The lesson from clinical trials is that circulating biomarkers such as ALP and PSA are indicators of overall response, however, they are indirect markers and do not furnish information about individual sites of involvement. Molecular imaging, on the contrary, might be able to depict the metabolic response in real time, allowing a tailored therapy.

Semi-quantitative PET scan with ${ }^{18} \mathrm{~F}$ at 12 weeks was reported in a pilot study as a better predictor of response (83), however, fluoride is a better indicator of bone remodeling rather than metastasis remission.

More recently, in a small series of patients, ${ }^{18} \mathrm{~F}$-choline (84) and ${ }^{68}$ Ga-PSMA (85), reflecting membrane metabolism and molecular expression, respectively, seem to be early biomarkers of tumor viability. In fact, acute metabolic changes can antedate morphological ones, enabling earlier assessment of tumor response, and the need for a change to another therapeutic approach, if indicated, can be met without waiting for disease progression.

\section{Administration Timing}

There is debate over the timing of ${ }^{223} \mathrm{Ra}$ administration, in particular, whether early administration in the course of disease is more convenient or should be delayed until the other options have been spent.

At present, except in registered and non-registered trials, the use of ${ }^{223} \mathrm{Ra}$ is allowed by national regulatory agencies in symptomatic patients with bone-metastatic CRPCa without visceral and nodal involvement. The possibility of extending its use to other phases of the disease can be postulated taking into account two points: i) the mechanism of action (alpha-particle emission) is unique, not shared with other drugs, independently of the true target of radioactive emission; ii) myelotoxicity is very low, allowing its association with other myelotoxic approaches such as chemotherapy or limited field EBRT. In fact, there are no theoretical or practical limitations to employing ${ }^{223} \mathrm{Ra}$ in association with other approaches in symptomatic patients with a large bone burden and visceral/nodal metastases. In fact many trials are addressing this.

On the other hand, a possible role in asymptomatic or oligosymptomatic patients with low-volume bone disease is also conceivable. Usually in these patients,individual localizations are of small volume and therefore more vulnerable to radiation effects. Prospective clinical trials are needed to confirm this hypothesis.

Animal studies have demonstrated that ${ }^{223} \mathrm{Ra}$ administration in a preventative or micrometastatic setting increased the time to death in both settings (28). To translate these results to humans is not a simple matter as far as administration time and selection of patients at high risk of developing bone metastases are concerned. However, it must be remembered that understaging of bone metastases with conventional diagnostic methods is most likely compared with PET molecular imaging, such as with ${ }^{18} \mathrm{~F}$-fluoride, ${ }^{11} \mathrm{C} /{ }^{18} \mathrm{~F}$-choline or ${ }^{68} \mathrm{Ga}$-PSMA $(79,80)$.

\section{Association, Sequence and Interactions}

The mechanism of action of ${ }^{223} \mathrm{Ra}$ is unique, therefore, in theory, it could be associated with other drugs either chemotherapeutical or hormonal agents for mCRPCa, but whether interaction exists is currently unknown.

In agreement with the data from the Expanded Access Program, the study of Dan et al. attested to the safety and tolerance of the combination of the concurrent use of ${ }^{223} \mathrm{Ra}$ and 
new anti-androgens, despite the limits of a small sample size, single institution and retrospective experience in heavily pretreated patients affected by massive bone marrow infiltration or with important residual chemotherapy toxicity (4).

The only reported positive interaction was the delay in SREs in patients administered bisphosphonates (19.6 vs. 10.2 months; HR=0.49; $p=0.00048$ ) (35).

Results of an international, early access, open-label, singlearm phase $3 \mathrm{~b}$ trial, recruiting patients with two or more skeletal metastases, symptomatic or asymptomatic, without visceral disease but with lymph node metastases, receiving ${ }^{223} \mathrm{Ra}$ plus abiraterone, enzalutamide or both, were recently published. The median OS was higher in these patients than in those who did not receive these agents, in addition, the association of denosumab with ${ }^{223} \mathrm{Ra}$ improved OS (5).

Association with chemotherapy may be necessary in order to cure coexisting visceral/nodal metastases, to improve the effect on bone metastases either in terms of tumor remission, or to improve the analgesic effect. Previous experiences with bone seeking beta-particle emitters are conflicting. Association of ${ }^{153} \mathrm{Sm}$-EDTMP with chemotherapy, EBRT and bisphosphonates gave advantages in terms of pain relief $(21,40,90)$.

The co-administration of ${ }^{89} \mathrm{Sr}$ with weekly doxorubicin was associated with improved survival in comparison to doxorubicin alone (10) while in a phase III prospective trial the association of low-dose cisplatinum with ${ }^{89} \mathrm{Sr}$ showed a significant effect on pain relief and duration, but not on OS (91).

In an observational study on 110 patients at the MD Anderson Cancer Center based on clinical experience, the chemotherapy regimen used concurrent with ${ }^{223} \mathrm{Ra}$ was not associated with an increased risk of bone marrow failure, while this risk was increased with the concomitant use of EBRT (92).

Recently a randomized phase II study comparing sipuleucel-T monotherapy $v s$. sipuleucel-T plus ${ }^{223} \mathrm{Ra}$ in patients with bone-metastatic CRPCa without visceral involvement was initiated (3).

Radiation has been implicated in immunogenic cell death and immunomodulation. Heery et al. demonstrated that ${ }^{153} \mathrm{Sm}$-EDTMP in association with a vaccine (PSA-Tricom) had the capability to alter tumor cell phenotype, making cells more amenable to T-lymphocyte assault (22).

In agreement with Umeweni et al. (56), and according to NICE, the placebo plus best standard-of-care adopted in the ALSYMPCA trial cannot be considered the standard of care for $\mathrm{mCRPCa}$ since NICE had recommended abiraterone for patients in the post-docetaxel regimen.

\section{Pharmacoeconomics}

Pharmacoeconomic implications are playing an increasing role in the treatment decision-making process (86). The costeffectiveness of new emerging treatments needs to be considered. The cost-effectiveness of ${ }^{223} \mathrm{Ra}$ is not well documented. In addition, although the managed agreements ensure patients have access to drugs, the market agreement between manufacturers and payers limits the transparency about the agreed prices for each pharmaceutical restricts the cost-effectiveness analysis.

Each scientific society provides its own recommendation for using ${ }^{223} \mathrm{Ra}$ (86), often not including a cost-effectiveness assessment, or not based on head-to-head comparison, as assessed by the American Society of Clinical Oncology and Cancer Care Ontario. The National Comprehensive Cancer Network considers ${ }^{223} \mathrm{Ra}$ as first- or second-line option for bone-metastatic CRPCa without visceral involvement and the European Association of Urology has recommended it in the post docetaxel setting, neither considering the costs. Similarly, the Norwegian Directorate of Health considers ${ }^{223} \mathrm{Ra}$ as available therapy for symptomatic bone metastatic disease after external radiotherapy and docetaxel but attested that it was not evaluated in an appropriate costeffectiveness analysis (86). The European Society of Medical Oncology has recommended ${ }^{223} \mathrm{Ra}$ or beta particleemitting radiopharmaceuticals for patients with bone symptomatic metastatic CRPCa (87) and the Sociedad Española de Oncología Médica (88) consider this radionuclide therapy acceptable if there are also affected nodes up to $2 \mathrm{~cm}$ in diameter.

Moreover, NICE did not consider ${ }^{223} \mathrm{Ra}$ cost-effective based on the comparison with best supportive care in the ALSYMPCA trial and the Institute for Health Technology Assessment underlined that it was also not compared with a valid competitor. The NICE committee considered the cost-effectiveness of ${ }^{223} \mathrm{Ra}$ compared with abiraterone only for patients previous treated with docetaxel, assuming a pragmatic approach, in an uncertain economic model that did not consider the additional costs associated with the administration of a radiopharmaceutical (56). The Swedish National Board for Health and Welfare evaluated the cost per quality-adjusted life-year related to ${ }^{223} \mathrm{Ra}$ therapy, which was very high, and restricted its use to that following chemotherapy. The Irish National Centre for Pharmacoeconomics also did not recommend the reimbursement of ${ }^{223} \mathrm{Ra}$ by its cost-effectiveness analysis. Bayer submitted an economic analysis on the comparison of ${ }^{223} \mathrm{Ra}$ with best supportive care administered to patients naïve to docetaxel and abiraterone administered to patients previously treated with docetaxel, with the limit of the different setting of the two treatments. A direct comparison between ${ }^{223} \mathrm{Ra}$ and docetaxel for patients newly diagnosed with metastatic CRPCa is lacking. Moreover, the Aberdeen Health Technology Assessment group advised an evaluation versus abiraterone as comparator (86).

We attempted to perform a cost-effectiveness analysis of ${ }^{223} \mathrm{Ra}$ in comparison with its non-chemotherapeutic competitors, abiraterone and enzalutamide. In order to 
calculate the incremental cost-effectiveness ratio (ICER), we considered the data published in the pivotal trials, and the costs relative to the median number of administered cycles were calculated on the ex-factory prices and based on the recommended daily dose, not considering the agreements between manufacturers and payers, nor other additional administration expenses relative to the different treatments. Costs were described in local monetary units. The effects were measured in terms of OS and described in months.

In our analysis, ${ }^{223} \mathrm{Ra}$ was compared with abiraterone acetate for patients both previously treated with and naïve for docetaxel $(35,57,48)$. The calculated ICER for ${ }^{223} \mathrm{Ra} v s$. abiraterone was 3175 (€35,242/€11.1) and 4412.20 $(€ 3,971 / € 0.9)$ in the pre- and post-docetaxel setting, respectively. In the same manner, we indirectly compared ${ }^{223} \mathrm{Ra}$ with enzalutamide. The ICER regarding patients treated early with docetaxel, as taken from the enzalutamide pivotal trial, was 1948.60 (50).

Since in Italy the acceptable range for ICER is between 12,000 and $60,000,{ }^{223} \mathrm{Ra}$ could be declared cost effective in all treatment setting for metastatic CRPCa. Clearly in our analysis, the limit related to the lack of a head-to-head comparison between the treatments still remains, with the approximate consideration of the ex-factory costs, not including the indirect costs linked to the route of administration. Abiraterone and enzalutamide are orally administered, saving expenditures associated with professional and hospitalization fees. The costs were also not corrected for quality-adjusted life-years since the lack of comparable evaluations of the quality of life between treatments and since the cost/OS gain would relate better than the cost/life-year gain to patients with limited survival expectancy (median OS gain $=90$ days) (89).

\section{Conclusion}

${ }^{223} \mathrm{Ra}$ dichloride is likely a powerful tool in the clinical armamentarium of innovative therapeutic options available for the treatment of mCRPCa. However, the gain in OS is controversial; despite being statistically significant, as it is suboptimal when ${ }^{223} \mathrm{Ra}$ was employed as monotherapy.

In our opinion, the main drawback to the use of ${ }^{22} \mathrm{Ra}$ is the lack of knowledge of the true target(s) of alpha-particle emission, with the classical model of a direct effect of radiation on cancer cells being able to explain only the response of very small metastatic deposits. In other words, a deeper insight into the mechanism of action on the tumor microenvironment may provide the rationale for an association of ${ }^{223} \mathrm{Ra}$ with other drugs and their sequential use in clinical practice. Another limit, shared with other drugs, is the lack of suitable biomarkers able to provide information in a real-time fashion about the response, either global or of any individual lesion, allowing clinical decision-making. In the same way, there is a substantial lack of knowledge on prognostic factors able to discriminate in advance responders from non-responders.

It is likely that molecular imaging will be able to answer the above questions, even if at present the proposed methods need to be validated in prospective trials.

A further matter of debate is in which phase of the disease, which frequently lasts several years, ${ }^{223} \mathrm{Ra}$ should be administered, whether only in when there is symptomatic large-volume bone disease or earlier in an asymptomatic low-volume start, or even in a micrometastatic setting.

The greatest challenge for investigators will be to determine timing and how to sequence or to combine the available therapies for mCRPCa.

\section{Acknowledgements}

The Authors would like to thank Dr. Federica Bocchio (Hospital Pharmacy, Fondazione IRCCS Policlinico San Matteo, Pavia, Italy) for her help in pharmacoeconomics.

\section{References}

1 King AJ, Evans M, Moore TH, Paterson C, Sharp D, Persad R and Huntley AL: Prostate cancer and supportive care: a systematic review and qualitative synthesis of men's experiences and unmet needs. Eur J Cancer Care 24: 618-634, 2015.

2 Hussain M, Tangen CM, Berry DL, Higano CS, Crawford ED, Liu G, Wilding G, Prescott S, Kanaga Sundaram S, Small EJ, Dawson NA, Donnelly BJ, Venner PM, Vaishampayan UN, Schellhammer PF, Quinn DI, Raghavan D, Ely B, Moinpour $\mathrm{CM}$, Vogelzang $\mathrm{NJ}$ and Thompson IM Jr.: Intermittent versus continuous androgen deprivation in prostate cancer. N Engl J Med 368: 1314-1325, 2013.

3 Park J, Sartor AO, Sullivan R, King S and Antonarakis ES: Randomized phase-2 study of sipuleucel-T with or without radium-223 in men with asymptomatic/minimally symptomatic bone-metastatic castrate-resistant prostate cancer (CRPC). J Clin Oncol 33: (suppl; abstr TPS5076), 2015.

4 Dan TD, Eldredge-Hindy HB, Hoffman-Censits J, Lin J, Kelly WK, Gomella LG, Lallas CD, Trabulsi EJ, Hurwitz MD, Dicker AP and Den RB: Hematologic toxicity of concurrent administration of radium-223 and next-generation antiandrogen therapies. Am J Clin Oncol 2015. doi: 10.1097/COC.00000 00000000181

5 Saad F, Carles J, Gillessen S, Heidenreich A, Heinrich D, Gratt J, Lévy J, Miller K, Nilsson S, Petrenciuc O, Tucci M, Wirth M, Federhofer J, O'Sullivan JM and Radium-223 International Early Access Program Investigators: Radium-223 and concomitant therapies in patients with metastatic castrationresistant prostate cancer: an international, early access, openlabel, single-arm phase $3 \mathrm{~b}$ trial. Lancet Oncol pii: S14702045(16)30173-5, 2016.

6 Florimonte L, Dellavedova L and Maffioli LS: Radium-223 dichloride in clinical practice: a review. Eur J Nucl Med Mol Imaging 43: 1896-1909, 2016. 
7 Dant JT, Richardson RB and Nie LH: Monte Carlo simulation of age-dependent radiation dose from alpha- and beta-emitting radionuclides to critical trabecular bone and bone marrow targets. Phys Med Biol 58: 3301-3319, 2013.

8 Abi-Ghanem AS, McGrath MA and Jacene HA: Radionuclide therapy for osseous metastases in prostate cancer. Semin Nucl Med 45: 66-80, 2015.

9 Maffioli L, Florimonte L, Costa DC, Correia Castanheira J, Grana C, Luster M, Bodei L and Chinol M: New radiopharmaceutical agents for the treatment of castration-resistant prostate cancer. Q J Nucl Med Mol Imaging 59: 420-438, 2015.

10 Tu SM, Millikan RE, Mengistu B, Delpassand ES, Amato RJ, Pagliaro LC, Daliani D, Papandreou CN, Smith TL, Kim J, Podoloff DA and Logothetis CJ: Bone-targeted therapy for advanced androgen-independent carcinoma of the prostate: a randomised phase II trial. Lancet 357: 336-341, 2001.

11 Silberstein EB: Teletherapy and radiopharmaceutical therapy of painful bone metastases. Semin Nucl Med 35: 152-158, 2005

12 Den RB, Doyle LA and Knudsen KE: Practical guide to the use of radium 223 dichloride. Can J Urol 21(Suppl 1): 70-76, 2014

13 Serafini AN, Houston SJ, Resche I, Quick DP, Grund FM, Ell PJ, Bertrand A, Ahmann FR, Orihuela E, Reid RH, Lerski RA, Collier BD, McKillop JH, Purnell GL, Pecking AP, Thomas FD and Harrison KA: Palliation of pain associated with metastatic bone cancer using samarium-153 lexidronam: a double-blind placebo-controlled clinical trial. J Clin Oncol 16: 1574-1581, 1998.

14 Tian JH, Zhang JM, Hou QT, Oyang QH, Wang JM, Luan ZS, Chuan L and He YJ: Multicentre trial on the efficacy and toxicity of single-dose samarium-153-ethylene diamine tetramethylene phosphonate as a palliative treatment for painful skeletal metastases in China. Eur J Nucl Med 26: 2-7, 1999.

15 Sartor O, Reid RH, Hoskin PJ, Quick DP, Ell PJ, Coleman RE, Kotler JA, Freeman LM, Olivier P and Quadramet 424Sm10/11 Study Group: Samarium-153-Lexidronam complex for treatment of painful bone metastases in hormone-refractory prostate cancer. Urology 63: 940-945, 2004

16 Turner JH, Claringbold PG, Hetherington EL, Sorby P and Martindale AA: A phase I study of samarium-153 ethylenediaminetetramethylene phosphonate therapy for disseminated skeletal metastases. J Clin Oncol 7: 1926-1931, 1989.

17 Resche I, Chatal JF, Pecking A, Ell P, Duchesne G, Rubens R, Fogelman I, Houston S, Fauser A, Fischer M and Wilkins D: A dose-controlled study of $153 \mathrm{Sm}$-ethylenediaminetetramethylenephosphonate (EDTMP) in the treatment of patients with painful bone metastases. Eur J Cancer 33: 1583-1591, 1997.

18 Sartor O, Reid RH, Bushnell DL, Quick DP and Ell PJ: Safety and efficacy of repeat administration of samarium Sm-153 lexidronam to patients with metastatic bone pain. Cancer 109: 637-643, 2007.

19 Borsò E, Boni G, Pastina I, Lorenzoni A, Cianci C, Federici F, Mazzarri S, Orlandini C, Francesca F, Selli C, Ricci S, Rubello D and Mariani G: Safety and antitumor efficacy of (153)SmEDTMP and docetaxel administered sequentially to patients with metastatic castration-resistant prostate cancer. Nucl Med Commun 35: 88-94, 2014.

20 Fizazi K, Beuzeboc P, Lumbroso J, Haddad V, Massard C, Gross-Goupil M, Di Palma M, Escudier B, Theodore C, Loriot Y, Tournay E, Bouzy $\mathrm{J}$ and Laplanche A: Phase II trial of consolidation docetaxel and samarium-153 in patients with bone metastases from castration-resistant prostate cancer. J Clin Oncol 27: 2429-2435, 2009.

21 Ricci S, Boni G, Pastina I, Genovesi D, Cianci C, Chiacchio S, Orlandini C, Grosso M, Alsharif A, Chioni A, Di Donato S, Francesca F, Selli C, Rubello D and Mariani G: Clinical benefit of bone-targeted radiometabolic therapy with ${ }^{153} \mathrm{Sm}$-EDTMP combined with chemotherapy in patients with metastatic hormone-refractory prostate cancer. Eur J Nucl Med Mol Imaging 34: 1023-1030, 2007.

22 Heery CR, Madan RA, Stein MN, Stadler WM, DiPaola RS, Rauckhorst M, Steinberg SM, Marté JL, Chen CC, Grenga I, Donahue RN, Jochems C, Dahut WL, Schlom J and Gulley JL: Samarium-153-EDTMP (Quadramet ${ }^{\circledR}$ ) with or without vaccine in metastatic castration-resistant prostate cancer: A randomized Phase 2 trial. Oncotarget : [Epub ahead of print], 2016.

23 Barendsen, GW: Responses of cultured cells, tumours and normal tissues to radiations of different Linear Energy Transfer. In: Ebert M, Howard A, editors, Curr Topics in Radiat Res Vol. IV. North-Holland, Amsterdam: 293-356, 1968.

24 Tinganelli W, Ma NY, Von Neubeck C, Maier A, Schicker C, Kraft-Weyrather W and Durante M: Influence of acute hypoxia and radiation quality on cell survival. J Radiat Res 54(Suppl 1): i23-i30, 2013.

25 El-Amm J and Aragon-Ching JB: Targeting bone metastases in metastatic Castration-Resistant Prostate Cancer. Clin Med Insights Oncol 10(Suppl 1): 11-19, 2016.

26 Neuman WF, Hursh JB, Boyd J and Hodge HC: On the mechanism of skeletal fixation of radium. Ann NY Acad Sci 62: 125-136, 1955.

27 Carrasquillo JA, O’Donoghue JA, Pandit-Taskar N, Humm JL, Rathkopf DE, Slovin SF, Williamson MJ, Lacuna K, Aksnes AK, Larson SM, Scher HI and Morris MJ: Phase I pharmacokinetic and biodistribution study with escalating doses of ${ }^{223} \mathrm{Ra}-$ dichloride in men with castration-resistant metastatic prostate cancer. Eur J Nucl Med Mol Imaging 40: 1384-1393, 2013.

28 Suominen MI, Rissanen JP, Käkönen R, Fagerlund KM, Alhoniemi E, Mumberg D, Ziegelbauer K, Halleen JM, Käkönen SM and Scholz A: Survival benefit with radium-223 dichloride in a mouse model of breast cancer bone metastasis. J Natl Cancer Inst 105: 908-916, 2013.

29 Henriksen G, Breistol K, Bruland OS, Fodstad O and Larsen RH: Significant antitumor effect from bone-seeking, alpha particle-emitting (223)Ra demonstrated in an experimental skeletal metastases model. Cancer Res 62: 3120-3125, 2002.

30 Henriksen G, Fisher DR, Roeske JC, Bruland OS and Larsen $\mathrm{RH}$ : Targeting of osseous sites with alpha-emitting ${ }^{223} \mathrm{Ra}$ : comparison with the beta-emitter $89 \mathrm{Sr}$ in mice. J Nucl Med 44: 252-259, 2003

31 Abou DS, Ulmert D, Doucet M, Hobbs RF, Riddle RC and Thorek DL: Whole-body and microenvironmental localization of Radium-223 in naïve and mouse models of Prostate Cancer Metastasis. J Natl Cancer Inst 108: pii djv380, 2015.

32 Xofigo radium Ra223 dichloride. European public assessment report (EPAR). http://www.ema.europa.eu/ema/index.jsp? curl=pages $/$ medicines/human/medicines/002653/human_med_00 1692.jsp\&mid=WC0b01ac058001d124 [Updated on 29/07/2016].

33 Vuong W, Sartor O and Pal SK: Radium-223 in metastatic castration resistant prostate cancer. Asian J Androl 16: 348-353, 2014. 
34 Pandit-Taskar N, Larson SM and Carrasquillo JA: Bone-seeking radiopharmaceuticals for treatment of osseous metastases, Part 1: $\alpha$ therapy with 223Ra-dichloride. J Nucl Med 55: 268-274, 2014.

35 Parker C, Nilsson S, Heinrich D, Helle SI, O'Sullivan JM, Fosså SD, Chodacki A, Wiechno P, Logue J, Seke M, Widmark A, Johannessen DC, Hoskin P, Bottomley D, James ND, Solberg A, Syndikus I, Kliment J, Wedel S, Boehmer S, Dall'Oglio M, Franzén L, Coleman R, Vogelzang NJ, O’BryanTear CG, Staudacher K, Garcia-Vargas J, Shan M, Bruland ØS, Sartor O and 3Investigators: Alpha emitter radium-223 and survival in metastatic prostate cancer. N Engl J Med 369: 213223, 2013.

36 Sartor O, Coleman R, Nilsson S, Heinrich D, Helle SI, O'Sullivan JM, Fosså SD, Chodacki A, Wiechno P, Logue J, Widmark A, Johannessen DC, Hoskin P, James ND, Solberg A, Syndikus I, Vogelzang NJ, O'Bryan-Tear CG, Shan M, Bruland $\emptyset S$ and Parker C: Effect of radium-223 dichloride on symptomatic skeletal events in patients with castration-resistant prostate cancer and bone metastases: results from a phase 3 , double-blind, randomised trial. Lancet Oncol 15: 738-746, 2014.

37 Nilsson S, Larsen RH, Fosså SD, Balteskard L, Borch KW, Westlin JE, Salberg G and Bruland OS: First clinical experience with alpha-emitting radium-223 in the treatment of skeletal metastases. Clin Cancer Res 11: 4451-4459, 2005.

38 Nilsson S, Franzén L, Parker C, Tyrrell C, Blom R, Tennvall J, Lennernäs B, Petersson U, Johannessen DC, Sokal M, Pigott K, Yachnin J, Garkavij M, Strang P, Harmenberg J, Bolstad B and Bruland OS: Bone-targeted radium-223 in symptomatic, hormonerefractory prostate cancer: a randomised, multicentre, placebocontrolled phase II study. Lancet Oncol 8: 587-594, 2007.

39 Bombardieri E, Evangelista L, Ceresoli GL and Boccardo F: Nuclear medicine and the revolution in the modern management of castration-resistant prostate cancer patients: from (223)Radichloride to new horizons for therapeutic response assessment. Eur J Nucl Med Mol Imaging 43: 5-7, 2016.

40 Hoskin P, Sartor O, O'Sullivan JM, Johannessen DC, Helle SI, Logue J, Bottomley D, Nilsson S, Vogelzang NJ, Fang F, Wahba M, Aksnes AK and Parker C: Efficacy and safety of radium-223 dichloride in patients with castration-resistant prostate cancer and symptomatic bone metastases, with or without previous docetaxel use: a prespecified subgroup analysis from the randomised, double-blind, phase 3 ALSYMPCA trial. Lancet Oncol 15: 1397-1406, 2014

41 O'Sullivan J, Johannessen DC, Widmark A, Syndikus I, James N, Dall'Oglio M, Haugen I, Cross A, Garcia-Vargas J and Vogelzang N: Hematologic safety of radium-223 dichloride (Ra223 ) in the phase 3 ALSYMPCA trial in castration-resistant prostate cancer (CRPC) patients with bone metastases: baseline prognostic factor subgroup analysis. ESMO/ECCO Proc 49: S688, 2013.

42 Bassler D, Briel M, Montori VM, Lane M, Glasziou P, Zhou Q, Heels-Ansdell D, Walter SD, Guyatt GH; STOPIT-2 Study Group, Flynn DN, Elamin MB, Murad MH, Abu Elnour NO, Lampropulos JF, Sood A, Mullan RJ, Erwin PJ, Bankhead CR, Perera R, Ruiz Culebro C, You JJ, Mulla SM, Kaur J, Nerenberg KA, Schünemann H, Cook DJ, Lutz K, Ribic CM, Vale N, Malaga G, Akl EA, Ferreira-Gonzalez I, Alonso-Coello P, Urrutia G, Kunz R, Bucher HC, Nordmann AJ, Raatz H, da Silva
SA, Tuche F, Strahm B, Djulbegovic B, Adhikari NK, Mills EJ, Gwadry-Sridhar F, Kirpalani H, Soares HP, Karanicolas PJ, Burns KE, Vandvik PO, Coto-Yglesias F, Chrispim PP and Ramsay T: Stopping randomized trials early for benefit and estimation of treatment effects: systematic review and metaregression analysis. JAMA 303: 1180-1187, 2010.

43 Omlin A, Pezaro C and Gillessen Sommer S: Sequential use of novel therapeutics in advanced prostate cancer following docetaxel chemotherapy. Ther Adv Urol 6: 3-14, 2014.

44 Tannock IF, de Wit R, Berry WR, Horti J, Pluzanska A, Chi KN, Oudard S, Théodore C, James ND, Turesson I, Rosenthal MA, Eisenberger MA and TAX 327 Investigators: Docetaxel plus prednisone or mitoxantrone plus prednisone for advanced prostate cancer. N Engl J Med 351: 1502-1512, 2004.

45 Petrylak DP, Tangen CM, Hussain MH, Lara PN Jr, Jones JA, Taplin ME, Burch PA, Berry D, Moinpour C, Kohli M, Benson MC, Small EJ, Raghavan D and Crawford ED: Docetaxel and estramustine compared with mitoxantrone and prednisone for advanced refractory prostate cancer. N Engl J Med 351: 15131520, 2004.

46 Kantoff PW, Higano CS, Shore ND, Berger ER, Small EJ, Penson DF, Redfern CH, Ferrari AC, Dreicer R, Sims RB, Xu Y, Frohlich MW, Schellhammer PF and IMPACT Study Investigators: Sipuleucel-T immunotherapy for castrationresistant prostate cancer. N Engl J Med 363: 411-422, 2010.

47 de Bono JS, Logothetis CJ, Molina A, Fizazi K, North S, Chu L, Chi KN, Jones RJ, Goodman OB Jr, Saad F, Staffurth JN, Mainwaring P, Harland S, Flaig TW, Hutson TE, Cheng T, Patterson H, Hainsworth JD, Ryan CJ, Sternberg CN, Ellard SL, Fléchon A, Saleh M, Scholz M, Efstathiou E, Zivi A, Bianchini D, Loriot Y, Chieffo N, Kheoh T, Haqq CM, Scher HI and COUAA-301 Investigators: Abiraterone and increased survival in metastatic prostate cancer. N Engl J Med 364: 1995-2005, 2011.

48 Ryan CJ, Smith MR, de Bono JS, Molina A, Logothetis CJ, de Souza P, Fizazi K, Mainwaring P, Piulats JM, Ng S, Carles J, Mulders PF, Basch E, Small EJ, Saad F, Schrijvers D, Van Poppel H, Mukherjee SD, Suttmann H, Gerritsen WR, Flaig TW, George DJ, Yu EY, Efstathiou E, Pantuck A, Winquist E, Higano CS, Taplin ME, Park Y, Kheoh T, Griffin T, Scher HI, Rathkopf DE and COU-AA-302 Investigators: Abiraterone in metastatic prostate cancer without previous chemotherapy. N Engl J Med 368: 138-148, 2013.

49 FDA approval for abiraterone acetate. Available from: http://www.cancer.gov/about-cancer/treatment/drugs/fdaabirateroneacetate [Updated: July 1, 2013].

50 Scher HI, Fizazi K, Saad F, Taplin ME, Sternberg CN, Miller K, de Wit R, Mulders P, Chi KN, Shore ND, Armstrong AJ, Flaig TW, Fléchon A, Mainwaring P, Fleming M, Hainsworth JD, Hirmand M, Selby B, Seely L, de Bono JS and AFFIRM Investigators: Increased survival with enzalutamide in prostate cancer after chemotherapy. N Engl J Med 367: 1187-1197, 2012.

51 Medivation and Astellas Announce the Phase 3 PREVAIL Trial of Enzalutamide Meets Both Co-Primary Endpoints of Overall Survival and Radiographic Progression-Free Survival in Chemotherapy-Naive Patients With Advanced Prostate Cancer. Available from: http://investors.medivation.com/ releasedetail .cfm?ReleaseID=798880 [October 22, 2013].

52 FDA approval for enzalutamide. Available from: http:// www.cancer.gov/about-cancer/treatment/drugs/fda-enzalutamide [Updated: July 3, 2013]. 
53 Saad F, Gleason DM, Murray R, Tchekmedyian S, Venner P, Lacombe L, Chin JL, Vinholes JJ, Goas JA, Chen B and Zoledronic Acid Prostate Cancer Study Group: A randomized, placebo-controlled trial of zoledronic acid in patients with hormone-refractory metastatic prostate carcinoma. J Natl Cancer Inst 94: 1458-1468, 2002.

54 Baur B, Solbach C, Andreolli E, Winter G, Machulla HJ and Reske SN: Synthesis, radiolabelling and in vitro characterization of the gallium-68-, yttrium-90- and lutetium-177-labelled PSMA ligand, CHX-A"-DTPA-DUPA-Pep. Pharmaceuticals 7: 517-529, 2014.

55 Gartrell BA, Coleman R, Efstathiou E, Fizazi K, Logothetis CJ, Smith MR, Sonpavde G, Sartor O and Saad F: Metastatic prostate cancer and the bone: significance and therapeutic options. Eur Urol 68: 850-858, 2015.

56 Umeweni N, Knight $\mathrm{H}$ and McVeigh G: NICE guidance on radium-223 dichloride for hormone-relapsed prostate cancer with bone metastases. Lancet Oncol 17: 275-276, 2016.

57 Fizazi K, Scher HI, Molina A, Logothetis CJ, Chi KN, Jones RJ, Staffurth JN, North S, Vogelzang NJ, Saad F, Mainwaring P, Harland S, Goodman OB Jr, Sternberg CN, Li JH, Kheoh T, Haqq CM, de Bono JS and COU-AA-301 Investigators: Abiraterone acetate for treatment of metastatic castrationresistant prostate cancer: final overall survival analysis of the COU-AA-301 randomised, double-blind, placebo-controlled phase 3 study. Lancet Oncol 13: 983-992, 2012.

58 Mohler JL, Kantoff PW, Armstrong AJ, Bahnson RR, Cohen M, D'Amico AV, Eastham JA, Enke CA, Farrington TA, Higano CS, Horwitz EM, Kawachi MH, Kuettel M, Lee RJ, Macvicar GR, Malcolm AW, Miller D, Plimack ER, Pow-Sang JM, Richey S, Roach M 3rd, Rohren E, Rosenfeld S, Small EJ, Srinivas S, Stein C, Strope SA, Tward J, Walsh PC, Shead DA, Ho $\mathrm{M}$ and National comprehensive cancer network: Prostate cancer, version 1.2014. J Natl Compr Canc Netw 11: 14711479, 2013.

59 Saad F, Carles J, Gillessen S, Heinrich D, Gratt J, Miller K, Nilsson S, O'Sullivan J, Tucci M, Wirth M and Heidenreich A: Radium-223 in an international early access program (EAP): Effects of concomitant medication on overall survival in metastatic castration-resistant prostate cancer (mCRCP) patients. J Clin Oncol 33(suppl; abstr): 5034, 2015.

60 Sartor AO, Fernandez DC, Morris MJ, Iagaru A, Brown A, Almeida F, Sweeney C, Smith MR, Dicker A, Wong YN, Shore ND, Gratt J, Petrenciuc O, Germino J and Vogelzang NJ: Ra223 experience in pretreated patients: EAP setting. J Clin Oncol 33(suppl; abstr): 5063, 2015.

61 Sternberg CN, Petrylak DP, Madan RA and Parker C: Progress in the treatment of advanced prostate cancer. Am Soc Clin Oncol Educ Book pp. 117-131, 2014.

62 Taneja SS: Re: Alpha Emitter Radium-223 and Survival in Metastatic Prostate Cancer. J Urol 191: 657, 2013.

63 Guerra Liberal FD, Tavares AA and Tavares JM: Palliative treatment of metastatic bone pain with radiopharmaceuticals: A perspective beyond Strontium-89 and Samarium-153. Appl Radiat Isot 110: 87-99, 2016.

64 Shore, an interview with OncLive "With Radium-223 Leading the Way, Use of Radiopharmaceuticals Continues to Evolve" Laura Panjwani http://global.onclive.com/web-exclusives/withradium-223-leading-the-way-use-of-radiopharmaceuticalscontinues-to-evolve [24/02/2016].
65 Hobbs RH, Song H, Watchman CJ, Bolch WE, Aksnes AK, Ramdahl T, Flux GD and Sgouros G: A bone marrow toxicity model for 223Ra alpha-emitter radiopharmaceutical therapy. Phys Med Biol 57: 3207-3222, 2012.

66 Bruland ØS, Nilsson S, Fisher DR and Larsen RH: High-linear energy transfer irradiation targeted to skeletal metastases by the alpha-emitter 223Ra: adjuvant or alternative to conventional modalities? Clin Cancer Res 12: 6250s-6257s, 2006.

67 Logothetis CJ: Prostate cancer bone metastases: not so systemic after all. Lancet Oncol 15: 675-676, 2014.

68 Economos C, Morrissey C and Vessella RL: Circulating tumor cells as a marker of response: implications for determining treatment efficacy and evaluating new agents. Curr Opin Urol 22: 190-196, 2012.

69 Koop S, MacDonald IC, Luzzi K, Schmidt EE, Morris VL, Grattan M, Khokha R, Chambers AF and Groom AC: Fate of melanoma cells entering the microcirculation: over $80 \%$ survive and extravasate. Cancer Res 55: 2520-2523, 1995.

70 Paget S: The distribution of secondary growths in cancer of the breast. 1889. Cancer Metastasis Rev 8: 98-101, 1989.

71 Psaila B and Lyden D: The metastatic niche: adapting the foreign soil. Nat Rev Cancer 9: 285-293, 2009.

72 Ganguly SS, Li X and Miranti CK: The host microenvironment influences prostate cancer invasion, systemic spread, bone colonization, and osteoblastic metastasis. Front Oncol 4: 364, 2014.

73 Weidle UH, Birzele F, Kollmorgen G and Rüger R: Molecular mechanisms of bone metastasis. Cancer Genomics Proteomics 13: 1-12, 2016.

74 Magnusson LU, Hagberg Thulin M, Plas P, Olsson A, Damber JE and Welén K: Tasquinimod inhibits prostate cancer growth in bone through alterations in the bone microenvironment. Prostate 76: 383-393, 2016.

75 Scher HI, Morris MJ, Stadler WM, Higano C, Basch E, Fizazi $\mathrm{K}$, Antonarakis ES, Beer TM, Carducci MA, Chi KN, Corn PG, de Bono JS, Dreicer R, George DJ, Heath EI, Hussain M, Kelly WK, Liu G, Logothetis C, Nanus D, Stein MN, Rathkopf DE, Slovin SF, Ryan CJ, Sartor O, Small EJ, Smith MR, Sternberg CN, Taplin ME, Wilding G, Nelson PS, Schwartz LH, Halabi S, Kantoff PW and Armstrong AJ: Trial design and objectives for Castration-Resistant Prostate Cancer: Updated recommendations from the Prostate Cancer Clinical Trials Working Group 3. J Clin Oncol 34: 1402-1418, 2016.

76 Fizazi K, Massard C, Smith M, Rader M, Brown J, Milecki P, Shore N, Oudard S, Karsh L, Carducci M, Damião R, Wang H, Ying $\mathrm{W}$ and Goessl $\mathrm{C}$ : Bone-related parameters are the main prognostic factors for overall survival in men with bone metastases from castration resistant prostate cancer. Eur Urol 68: 42-50, 2015.

77 Etchebehere EC, Araujo JC, Fox PS, Swanston NM, Macapinlac HA and Rohren EM: Prognostic factors in patients treated with ${ }^{223} \mathrm{Ra}$ : The role of skeletal tumor burden on baseline ${ }^{18} \mathrm{~F}-$ Fluoride PET/CT in predicting overall survival. J Nucl Med 56: 1177-1184, 2015.

78 Halabi S, Kelly WK, Ma H, Zhou H, Solomon NC, Fizazi K, Tangen CM, Rosenthal M, Petrylak DP, Hussain M, Vogelzang NJ, Thompson IM, Chi KN, de Bono J, Armstrong AJ, Eisenberger MA, Fandi A, Li S, Araujo JC, Logothetis CJ, Quinn DI, Morris MJ, Higano CS, Tannock IF and Small EJ: Meta-Analysis evaluating the impact of site of metastasis on Overall Survival in men with castration-resistant prostate cancer. J Clin Oncol 34: 1652-1659, 2016. 
79 Fanti S, Minozzi S, Castellucci P, Balduzzi S, Herrmann K, Krause BJ, Oyen W and Chiti A: PET/CT with (11)C-choline for evaluation of prostate cancer patients with biochemical recurrence: meta-analysis and critical review of available data. Eur J Nucl Med Mol Imaging 43: 55-69, 2016.

80 Evangelista L, Cimitan M, Zattoni F, Guttilla A, Zattoni F and Saladini G: Comparison between conventional imaging (abdominalpelvic computed tomography and bone scan) and [(18)F]choline positron emission tomography/computed tomography imaging for the initial staging of patients with intermediate-to high-risk prostate cancer: A retrospective analysis. Scand J Urol 49: 345-353, 2015.

81 Pfister D, Porres D, Heidenreich A, Heidegger I, Knuechel R, Steib F, Behrendt FF and Verburg FA: Detection of recurrent prostate cancer lesions before salvage lymphadenectomy is more accurate with (68)Ga-PSMA-HBED-CC than with (18)FFluoroethylcholine PET/CT. Eur J Nucl Med Mol Imaging 43: 1410-1407, 2016.

82 Eisenhauer EA, Therasse P, Bogaerts J, Schwartz LH, Sargent D, Ford R, Dancey J, Arbuck S, Gwyther S, Mooney M, Rubinstein L, Shankar L, Dodd L, Kaplan R, Lacombe D and Verweij J: New response evaluation criteria in solid tumours: revised RECIST guideline (version 1.1). Eur J Cancer 45: 228247, 2009

83 Cook G Jr., Parker C, Chua S, Johnson B, Aksnes AK and Lewington VJ: ${ }^{18} \mathrm{~F}$-fluoride PET: changes in uptake as a method to assess response in bone metastases from castrate-resistant prostate cancer patients treated with 223Ra-chloride (Alpharadin). EJNMMI Res 1: 4, 2011.

84 Miyazaki KS, Kuang Y and Kwee SA: Skeletal changes in tumor activity on (18)F-choline PET/CT in patients receiving (223)Radium radionuclide therapy for metastatic prostate cancer. Nucl Med Mol Imaging 49: 160-164, 2015.

85 Ahmadzadehfar H, Schlenkhoff CD, Rogenhofer S, Yordanova A and Essler M: 68Ga-PSMA-11 PET represents the tumoricidal effect of ${ }^{223} \mathrm{Ra}$ in a patient with castrate-resistant metastatic prostate Cancer. Clin Nucl Med 41: 695-696, 2016.
86 Norum J, Traasdahl ER, Totth A, Nieder C and Olsen JA: Health economics and Radium-223 (Xofigo ${ }^{\circledR}$ ) in the treatment of metastatic Castration-Resistant Prostate Cancer (mCRPC): A case history and a systematic review of the literature. Glob J Health Sci 8: 1-9, 2015.

87 Horwich A, Parker C, de Reijke T and Kataja V: On behalf of the ESMO Guidelines Working Group. Prostate cancer: ESMO Clinical Practice Guidelines for diagnosis, treatment and followup. Ann Oncol 24(Suppl 6): vi106-vi114, 2013.

88 Cassinello J, Climent MA, González del Alba A, Mellado B and Virizuela JA: SEOM Clinical guidelines for the treatment of metastatic prostate cancer. Clin Transl Oncol 16: 1060-1066, 2014.

89 Guirgis HM: The value of anticancer drugs in metastatic castrate-resistant prostate cancer: economic tools for the community oncologist. J Community Support Oncol 13: 362366, 2015.

90 Borsò E, Mazzarri S, Boni G, Cianci C, Tosi D, Sansovini M, Baldari S, Vuillez J, Morel O, Veltri M, Schiavo R, Orlandini C, Ricci S and Mariani G: The SAMDOCET study. Eur J Nucl Med 40(Suppl 2): S497, 2013.

91 Sciuto R, Festa A, Rea S, Pasqualoni R, Bergomi S, Petrilli G and Maini CL: Effects of low-dose cisplatin on ${ }^{89} \mathrm{Sr}$ therapy for painful bone metastases from prostate cancer: a randomized clinical trial. J Nucl Med 43: 79-86, 2002.

92 Etchebehere EC, Milton DR, Araujo JC, Swanston NM, Macapinlac HA and Rohren EM: Factors affecting (223)Ra therapy: clinical experience after 532 cycles from a single institution. Eur J Nucl Med Mol Imaging 43: 8-20, 2016.

Received August 19, 2016

Revised September 29, 2016

Accepted October 10, 2016 